New Katherine A. $B A, M A(O x o n)$ аспирант, фбакультет средневековых и совреленных языков, Оксфордский университет (Великобритания) University College, High Street, Oxford, OX14BH

Тел.: 01865-276602

E-mail: katherine.new@univ.ox.ac.uk

\title{
From IMITATION TO REFUTATION: THE CANONISATION AND DECANONISATION OF THE METAPHOR OF A POETIC MONUMENT IN RUSSIAN LITERATURE
}

\begin{abstract}
Аннотация. В статье анализируется метафора поэзии как нематериального памятника, увековечивающего заслуги поэта, на примере рецепции оды Горация 3.30 в русской литературе (от Державина и Пушкина до Брюсова, Маяковского, Ходасевича, Бродского, Заходера и Пурина, чьи стихотворения до сих пор, насколько известно, не привлекали внимания исследователей). Изучение поэзии, основанной на метафоре поэтического памятника, позволяет выделить ее характерные черты: интертекстуальность, выражающуюся в цитатах, аллюзиях, пародиях, бриколаже, пастише; доминирование мотива поэтической эгоцентричности; развертывание метафоры памятника во временно́й и пространственной перспективах. Метафора поэтического памятника становится фактом русской литературы благодаря Ломоносову и Державину, однако своей необыкновенной популярностью в России (несравнимой с ее судьбой ни в одной литературной традиции) ода Горация обязана стихотворению Пушкина, с которого начинается разрушение канонического осмысления метафоры поэзии как невербального памятника. Полемические отклики Брюсова и Маяковского направлены на стихотворение Пушкина, подтверждая постоянное присутствие метафоры поэтического памятника в коллективной памяти наций, говорящих на русском языке. Пародийное осмысление продолжает процесс деканонизации литературной традиции, показывая ее важность для современной культуры, которая подвергает рассматриваемую метафору «остранению» травестией, как в стихотворении Бродского, или иронией, как в стихах Ходасевича или Заходера, или бриколажем, как в «Памятнике» Пурина. Традиция, основанная на метафоре невербального памятника, трансформированная, но не уничтоженная пародией, представляет собой открытую систему, а потому ее пародийное (или каноническое) осмысление скорее всего обречено на продолжение в постмодернистской литературе.
\end{abstract}


Ключевые слова: метафора, поэтический памятник, интертекстуальность, аллюзия, цитата, бриколаж, пародия, пространственная перспектива, временная перспектива, хронотоп

$\mathrm{P}$ ushkin’s famous poem “Я памятник себе воздвиг нерукотворный...”, in which "the poet becomes the verbal sculptor of his own monument" [Kahn 2008: 82], has attracted the attention of many scholars ${ }^{1}$, but has rarely become an object of comparative study. Nearly a century ago Georgii Shengeli studied the versification of Pushkin's and Bryusov's poems, underlining the modernistic nature of the latter against the background of the Russian tradition [Шенгели 1918]. Саtriona Kelly, on the contrary, expressed the view that in Pushkin's poem "the idea of an art work about the impossibility of making an art work", "seems Modernistic rather than Romantic" [Kelly 2001: 12]. The historical development of an odic tradition was studied by Lev Pumpianskii, who showed through minute textual analysis the deviations of Pushkin's and Derzhavin's poems from Horace's Ode 3.30 [Пумпянский 1977].

The semantics and the internal structure of statue imagery in Pushkin's poetry with reference to his verbal monument were outlined by Roman Jakobson [Якобсон 1987] whose views were developed in Sergey Zhiliakov's dissertation, dedicated to the reconstruction of a specific genre of monument poems, combining the features of testaments, lamentations, epitaphs, poetic prayers, consolations [Жиляков 2010]. Unlike Zhiliakov's dissertation, which centres on poetic descriptions of material monuments $^{2}$, this article will attempt to distinguish between poems based on the metaphoric and the material representations of monuments. Following the views expressed by Andrew Kahn, who stresses the "unphysical essence of the monument" in Pushkin's poem [Kahn 2008: 82], this article will focus on texts based on the metaphoric representation of the immaterial verbal monument, traceable to Horace's Ode 3.30.

The most extensive study of the Russian monument tradition based on Pushkin's famous poem was made in the monograph by M. P. Alekseev, who included translations of Horace's ode [Алексеев 1967] without explicitly distinguishing them from poetic imitations. The study of translated texts ${ }^{3}$, however, is necessarily concerned with voluntary or involuntary deviations from the original, which presents limited scope for studying the metaphor of verbal monument.

The aim of this article is to analyze the artistic imitations of Horace's ode, whose main function is, to use Roman Jakobson's terminology [Якобсон 1975: 193-230], poetic rather than communicative. The methodology employed in this

1 The extensive review of the scholarly debate around Pushkin's poem is outlined in M. P. Alexeev's book [Алексеев 1967].

${ }^{2}$ Zhiliakov's dissertation does not draw a distinction between the metaphorical representation of monuments and their material form, described in Mayakovsky's "Юбилейное", Vysotsky's “Памятник", Iaroslav Smeliakov's, Lev Losev's “Памятник", and mostly concentrates on the latter.

${ }^{3}$ Such as the texts by M. V. Lomonosov, G. R. Derzhavin, V. V. Kapnist, A. Kh. Vostokov, S. A. Tuchkov, A. A. Fet, N. F. Fokkov, B. V. Nikolskii, P. F. Porfirov, V. Ya. Bryusov (1913, 1918), V. N. Krachkovskii, A. P. Semenov-Tianshanskii, N. I. Shaternikov, Ia. E. Golosovker, which are quoted in Alekseev's book. 
article is based on the works of Mikhail Gasparov, who focuses on unnoticed shades of meaning and the selection and succession of images with the purpose of reconstructing the poetic system of the text as a whole [Гаспаров 2000]. These methods of research can be applied to the study of the metaphor of verbal monument based on Horace's Ode 3.30 (from Derzhavin and Pushkin to Bryusov, Mayakovsky, Khodasevich, Brodsky, Zakhoder and Purin, whose works have not been analysed before), with focus on the mechanisms of intertextuality: quotation, allusion, bricolage, pastiche, parody.

Intertextuality appears to be a necessary requirement of the poetic monument tradition, as can be seen in the numerous predecessors of Horace's ode: an Egyptian papyrus of c. $1200 \mathrm{BC}$, praising ancient scribes who "did not make themselves pyramids of bronze with iron plaques $\langle\ldots\rangle$ their teachings are their pyramids; $\langle.$.$\rangle their$ monuments are covered with earth $\langle. .$.$\rangle but their names are mentioned because of$ their books" [West 1969: 132]; Pindar's claim that "a ready-built treasury house of songs for Pythian victory has been erected in Apollo's golden valley. This neither winter's rain, coming in an implacable alien host of roaring cloud, nor wind will drive into the hollows of the sea, pounded with jumbled debris" [Lowrie 1997: 72] ${ }^{4}$; Aristophanes' masonry metaphors applied to Aeschylus's verses [Taillardat 1962: 438]; Callimachus's fragment representing two temples in terms suggestive of poetry [Thomas 1999: 76]; Virgil depicting his future epic as a marble temple [Suerbaum 1968: 172-175]; Simonides's dirge on the dead at Thermopylae, stating that "his tribute, unlike material offerings, will not be dimmed by decay or time" [Harrison 2001: 261]; an epitaph attributed to Cleobulus, describing how "a bronze statue on the tomb of Midas will last as long as water flows and trees are green" [Slings 2000: 7]. Although Horace's ode might include allusions to or direct quotations from any of these, the most striking are the textual parallels with the Egyptian papyrus, where imagery develops from concrete material constructions (pyramids of bronze) to the immaterial pyramids of the scribe's teachings; the image of transience, revealed through destructible material monuments covered with earth (prefiguring the image of death and immortality central to the poetic monument tradition), is contrasted with the image of indestructibility, represented by texts, i. e. verbal monuments.

The metaphor of poetry as an immaterial construction is one of the early topoi of ancient literature preceding Horace's ode: it appears in Callimachus, Pindar, Aristophanes and Virgil. The notion of the durability of verbal art in time and space is expressed through the poetic device of adynaton (which will become characteristic of the monument tradition) in Virgil, Simonides, Cleobulus, Pindar and in the Egyptian papyrus. The notions of time and/or space are viewed by Horace's predecessors as challenges to their immaterial monuments but do not participate in the spatial or temporal organisation of their texts.

In Horace's ode the spatial-temporal structure is revealed by means of a double perspective, that of time, prevailing in the beginning of the poem, and of space, dominating towards the end [Гаспаров 2000]. The image of time, viewed as an antagonist of the poet's verbal monument, is given physical embodiment at the beginning of the poem, where it is molded into material manifestations (bronze and

${ }^{4}$ Commentators on Pindar do not "equate the building with poetry but rather with the fame of the victor as embodied in the poetry" [Lowrie 1997: 73]. Cf. also: [Bowra 1964: 20-23, 323]. 
pyramids). The monument is said to be "more lasting than bronze" (aere perennius) 5 and "loftier than the regal structure of the pyramids" (regalique situ Pyramidum altius, 2$)^{6}$, pyramids themselves being material symbols of time. The image of time seen in material terms develops into an image of immaterial eternity: the monument cannot be destroyed "by the countless succession of years and the flight of time" (innumerabilis / annorum series et fuga temporum, 4-5), paradoxically expressing the idea of time as being "both infinite and also fugitive" [Nisbet, Rudd 2004: 371]. Immaterial eternity turns into personal immortality ("I shall not wholly die, a great part of me will escape Libitina", non omnis moriar, / multaque pars mei vitabit Libitinam, 6-7) and immortal fame ("I shall always grow in praise with posterity", usque ego postera / crescam laude recens, 8). The scope of the metaphor of the verbal monument is thus widened from the material to the immaterial, immortal and eternal.

Having reached the semantics of eternity, the temporal perspective cannot be widened any further and therefore gives way to the imagery of space, which starts to expand from the concrete toponyms in the precise middle of the poem (line 8 out of 16): the Capitol, being a symbol of Roman imperium [Nisbet, Rudd 2004: 373], where a priest climbs with the silent vestal virgin (dum Capitolium / Scandet cum tacita virgine pontifex, $8-9^{8}$ ). The virgin is silent, as if deprived of speech by the solemnity of the procession ${ }^{9}$, and is implicitly contrasted with the poet, who is endowed with the gift of poetic speech. The shift of perspective takes the audience from the very centre of "speechless" Rome to Horace's homeland (in the south of Italy, Venusia), where the violent Aufidus, the chief river of Apulia, roars (qua violens obstrepit Aufidus, 10) [Nisbet, Rudd 2004: 374]. The implied contrast between the noise of Apulia and the quiet of the procession in Rome draws on imagery not only of space but also of sound and speech.

The spatial scope introduced by using a hydronym as synecdoche to refer to Horace's birthplace is widened in the metonymy of the proper name, Daunus ${ }^{10}$,

${ }^{5}$ The text of Horace's Odes is quoted from [West 2009]. The noun "aere", literally meaning bronze, can also be used to denote the bronze statues erected to commemorate victorious warriors or sportsmen, or alternatively coins, which, during the years of the Roman Principate, were imprinted with the image of the emperor. Thus, the point of Horace's comparison is to contrast the material concept of money (or statues) and earthly sovereignty, which are doomed to be destroyed by time and forgotten, and the power of his poetic art, which is immortal [Nisbet, Rudd 2004: 368-369].

${ }^{6}$ The word-combination "regali situ Pyramidum" presents difficulties to interpreters. The noun "situs" is sometimes understood as meaning 'structure', however its other meaning is 'decay'; the word-combination then can be viewed as including a genitivus inversus, i. e. an abstract noun accompanied by another noun in the genitive case, used instead of a combination of an adjective with a noun [West 2009: 261].

${ }^{7}$ Libitina - the Roman goddess of funerals.

8 "The ascent of the high priest with his properly subordinated, chaste, and silent female companion underscores the decorous reallocation of sexual and verbal powers that has cleared the way for Horace's triumph" [Oliensis 1998: 103].

${ }^{9}$ The spatial dimension in the description of the procession is united with the temporal image, as "the future life of Rome with its unalterable ceremonies is taken for granted, if not to the end of all time, yet for so immense a period that no one needs to cast his thought beyond it" [Fraenkel 1957: 303].

${ }^{10}$ Daunus was a legendary Greek from Illyria, who founded Daunia, part of Apulia [Nisbet, Rudd 2004: 372]. 
referring to Apulia ("where Daunus, poor in water, ruled rustic peoples", qua pauper aquae Daunus agrestium / regnavit populorum, 11). The perspective is further widened in the reference to the poet's homeland, with which his "local pride" ("but local pride seen sub specie aeternitatis" [Commager 1966: 314]) is associated: "it shall be said of me $\langle. .$.$\rangle that I, powerful from my lowly origin, was the first to have$ brought Aeolian song to Italian measures" (dicer ‘... ex humili potens / princeps Aeolium Carmen ad Italos / deduxisse modos, 10-14). The statement of the poet's achievement, consisting in composing Latin poetry in Greek lyric metres for the benefit of a Roman audience, encompasses the whole poetic oikumena, thus widening the perspective almost to the immeasurable.

The poet can therefore justly claim what he deserves when asking Melpomene to "take up the pride obtained by [your] merits and graciously encircle my [your] head with Delphic laurel" (Sume superbiam / Quaesitam meritis et mihi Delphica / Lauro cinge volens, Melpomene, comam, 14-16). The Delphic laurel was bestowed upon victorious athletes in Apollo's Pythian Games and had never been awarded for poetry; granting this honour to a poet is Horace's invention, and he has nominated himself to receive it [Pöschl 1970: 260; Nisbet, Rudd 2004: 369]. The poet's address to Melpomene is justified by the widest temporal perspective of eternity and the widest spatial perspective of the entire poetic universe, in which the poet's metaphoric monument is placed.

The development of images of time and space in Horace's poem can be viewed through two reverse perspectives: the objects are widened the further they are from the spectator. The temporal perspective is represented first through bronze, then through the pyramids, then through the unnumbered procession of years and the flight of time; the spatial perspective widens out from the Capitoline hill to Apulia and finally to the whole poetic universe. The metaphor of the monument therefore can be said to expand from the material to the infinite in its spatial perspective and from the concrete to the eternal in its temporal scope.

The expansion of the metaphor, reflected in the spatial-temporal structure of the ode, creates the context for introducing a completely new motif, which had not appeared in Horace's predecessors. This new motif may be termed the poet's "egocentricity": the creation of the verbal monument is linked to the motif of individual immortality achieved by the fame of the poet's works. The poet's contribution to art is assessed through references to his own homeland and humble origin, i. e. his poetic "biography" [Веселовский 1989: 218]. The logical conclusion of Horace's ode is also innovative: the metaphor of verbal monument, unfolded through time and space, justifies the poet's address to the Muse, asking her to crown his glory with laurel symbolising his fame.

In Russia the canonisation of the metaphor of a poetic monument, expanded by Horace, starts with Lomonosov's translation of Ode 3.30 ${ }^{11}$. However Derzhavin's "Памятник" (1795), the first poetic imitation of Horace's ode, makes the metaphor

${ }^{11}$ Lomonosov's translation differs from Horace's ode in that the word "monument" is replaced by the word "sign" (“Я знак бессмертия себе воздвигнул"); the reference to the Capitol is replaced by a reference to Rome ("Я буду возрастать повсюду славой, / Пока великий Рим владеет светом"); the hydronym and the mythological name are interpreted not as references to the poet's homeland but as places of his future glory [Пумпянский 1977]. Lomonosov's text is quoted from [Ломоносов 1986]. 
of verbal monument a fact of Russian literature. Derzhavin's poem bears the constituent features of the tradition, primarily its intertextuality ${ }^{12}$ : it responds not only to Horace's ode but also to Lomonosov's translation. Intertextuality accounts for the description of Russia through hydronyms, which has been interpreted as a result either of contamination with another of Horace's odes (2.20) [Гаспаров 2000] or of following Lomonosov's translation (1748). The single Latin hydronym of Horace's original and of Lomonosov's translation gives way in Derzhavin's poem to several Russian toponyms: the names of seas (White Sea and Black Sea), rivers (Volga, Don, Neva, Ural), and a mountain in its ancient classical guise ${ }^{13}$.

This attention to geographical detail can be accounted for by its intertextuality: the influence of other Lomonosov's poems, in which similar lists of toponyms can be found (“В полях, исполненных плодами, / Где Волга, Днепр, Нева и Дон...” [Ломоносов 1959: 222]; “На север и на юг, на запад и восток, / Где Волга, Днепр, Двина, где чистый Невский ток / Между Петровых стен ликуя протекает" [Ibid.: 497]); the desire to compare the fame of the poet with the extensive fame of a ruling monarch ${ }^{14}$; the tendency to liken Russia to the Roman Empire with respect to the number of toponyms it includes; or the spirit of the age of geographical discoveries ${ }^{15}$. Whichever of these intertextual reasons for the introduction of geographical details prevail, the change in the representation of space relative to Horace's ode is obvious. The expansion of the geographical area, underlined by including the names of rivers encompassing the whole country, inevitably implies magnification of immortal fame. In Derzhavin's text, the poet's immortality is perceived in toponymic and hydronymic, i. e. geographical terms.

As in Horace's ode and Lomonosov's translation, the metaphor of poetic monument in Derzhavin's "Памятник” is unfolded through the temporal-spatial structure of his text. The temporal perspective first narrows from the image of the eternal monument ("Я памятник себе воздвиг чудесный, вечный”) ${ }^{16}$ which is harder than the material metals and the pyramids ("Металлов тверже он и выше пирамид”), to the fleeting thunderstorm ("Ни вихрь его, ни гром не сломит быстротечный"), and then widens to the abstract flight of time ("И времени полет его не сокрушит" $)^{17}$. The temporal perspective, developed in the first stanza, gives way

12 “...In the intertextual relations between a classical Latin source and imitations by Russian poets (Derzhavin, Lomonosov and Pushkin) at the transition from Classism to Romanticism the dialogic tension intensified and the sense of historical, linguistic and cultural otherness of the source became sharper" [Juvan 2008: 31].

13 "Riphaei montes" (the Riphaean mountains) was the name for the Urals or the Caucasus in classical treatises on geography.

14 “Самый географический размах поэтической славы - это географический размах оды: поэтическая слава занимает в точности то же пространство, что и могущество торжествующего монарха, и описывается той же самой традиционной формулой — (от... до...)" [Живов 1996: 678].

${ }^{15}$ The $18^{\text {th }}$ century was an age of geographical discoveries; the expeditions of the Academy of Sciences showed that Russia, following Spain and Portugal, could contribute to the investigation of the globe [Пумпянский 1977, Мусорина 2000].

${ }^{16}$ The text of Derzhavin's poem is quoted from [Державин 1957: 417].

${ }^{17}$ Derzhavin's poem became the model for Pushkin's younger contemporary N. M. Iazykov, whose "Стихи на объявление памятника историографу Н. М. Карамзину” [Языков 1858] glorify not his own literary achievements but Karamzin's and therefore fall outside the scope of the present article. 
to the spatial perspective, narrowing from the whole universe ("Доколь славянов род вселенна будет чтить”) to a list of concrete hydronyms (“Слух пройдет обо мне от Белых вод до Черных, / Где Волга, Дон, Нева, с Рифея льет Урал”) and then to innumerable nations ("Всяк будет помнить то в народах неисчетных").

The expansion of the verbal monument metaphor is developed in Derzhavin's poem by combining linear perspective (narrowing the temporal focus from the eternal to the concrete) and reverse perspective (widening the temporal perspective from the concrete to the Horatian abstract image of "the flight of time"). The image of space narrows from the reference to the universe to the list of concrete toponyms, given in the order of linear perspective from the seas to the rivers, and finally widening again to the immeasurable and the immortal, thus combining the linear and the reverse perspectives. This combination results in a deepening of perception: the close plane is perceived in reverse perspective and the distant plane is perceived in linear perspective, thus creating the so-called "perceptive perspective"18.

This new combined perspective paves the way for the introduction of a personal moral aspect, which is absent in Horace's ode ${ }^{19}$. The poet's achievement is cast as a triad combining the functions of poetry as panegyric and entertainment; philosophical and theological; and instructive or illuminative ${ }^{20}$. In comparison with Horace's ode, "egocentricity" is enhanced in Derzhavin's poem: the highly personal terms in which he speaks about his achievements are reflected in the frequent use of the singular personal pronoun, occurring in his text six times. Egocentricity is further developed in the poet's address to the Muse, which incorporates the motif of pride (expressed in Horace in the single word "superbia", combining the connotations of haughtiness and condescension and brought out in Derzhavin's line, “возгордись заслугой справедливой, / И презрит кто тебя, сама тех презирай" ${ }^{21}$ ), and concludes with a request to crown herself not with the Delphic laurel but with no less than the "dawn of immortality" (“Чело твое зарей бессмертия венчай”). Egocentricity, as well as intertextuality and the "monument chronotope" in its Horatian form $^{22}$, can be said to have become structural features of the tradition of monument poems, which achieve canonisation through Derzhavin's ode.

The temporal-spatial characteristics of the poetic monument metaphor are transformed in Pushkin's “Я памятник себе воздвиг...”, whose epigraph, "Exegi monumentum" 23 , is taken as a quotation from Horace and, through its intertextuality, raises uncertainty as to whether the poem is an imitation of the Roman ode or an answer to it. In using the word "monumentum" both Horace and Pushkin play on the ambiguity of its meaning, creating a posthumous feel as if their poems were

${ }^{18}$ The term "perceptive perspective" (“перцептивная перспектива”) was elaborated in [Paушенбах 1986].

${ }^{19}$ The study of Derzhavin's ode in the light of the historical, cultural and biographical facts has shown that its composition reflects similarities of the poet's fate with Horace's [Клейн 2004: 148-169].

${ }^{20}$ For Derzhavin's image of the poet [Песков 1984: 17].

${ }^{21}$ An addition to the study of the intertextuality of Derzhavin's poem was made by D. Bethea, interpreting this line as a major deviation from Horace's ode [Bethea 1998: 232].

${ }^{22}$ The combined spatial-temporal relationship in poems based on the metaphor of the poetic monument will be referred to as "chronotopical", following M. Bakhtin's terminology [Бахтин 1975].

${ }^{23}$ The texts of Pushkin's poems are quoted from [Пушкин 1962-1965]. 
composed on the other side of the grave ${ }^{24}$. Instead of Horace's contrast between the metaphorical "monumentum" and a material value (indicated by the comparative ending of the adjective in "aere perennius"), Pushkin creates a paradox [Kahn 2008: 84] between the physical image of a monument and the idea of it being unmade, employing the polysemantic adjective "нерукотворный" 25.

The beginning of the second stanza of Pushkin's "Памятник", which predicts the poet's future immortality, "Нет, весь я не умру" is another direct quotation from Horace's Ode 3.30 "Non omnis moriar", preserving the intertextual connection between the two poems. The continuation of the same stanza: “душа в заветной лире / мой прах переживет и тленья убежит" although deviating from the rest of Ode 3.30, contains an idea similar to that found in Horace's Ode 4.9: "time hasn't erased what Anacreon once / played: and the love of the Lesbian girl still / breathes, all the passion that Sappho / committed to that Aeolian lyre" [Войтехович 2000]. In both poems the lyre becomes a metaphor for poetry and for the way in which each poet will be remembered. However, Pushkin's lyre has a meaningful epithet “заветная", which has connotations of a commandment, a covenant, a testament.

In contrast to Horace's ode and Derzhavin's "Памятник", which developed the temporal and the spatial perspectives in succession, Pushkin deals with both perspectives simultaneously ${ }^{26}$. The temporal scope of the poet's fame is narrowed from "as long as a single poet is alive" (“доколь в подлунном мире / Жив будет хоть один пиит"), to the adverb "long" in a reference to the people ("И долго буду тем любезен я народу") and concludes with reference to "my cruel time" ("мой жестокий век"). Temporal perspective thus develops from the epochs of successive generations of poets (adynaton is used to convey the idea of eternity) to a human life-span and finally to the poet's own "cruel time", thus using linear perspective to narrow the scope of vision.

Whereas the focus of time steadily narrows, the image of space synchronically widens from the reference to the people's path to the metonymic denotation of monarchy (“Александрийского столпа", in which the dialogue with Derzhavin's text, with its reference to monarchs, cf. "истину царям", can be perceived) ${ }^{27}$. Spatial perspective further widens in the reference to isolated poets existing in the sublunary

${ }^{24}$ Both Horace and Pushkin conjure up two possible meanings, an honorary monument such as was erected in Rome for eminent citizens during their lifetime or a funerary monument marking a person's grave [Williams 1969: 150; Сурат 2009: 254-256].

${ }^{25}$ In 1933 I. L. Feinberg suggested a link between Pushkin's poem and the poem composed by V. G. Ruban on the monument to Peter the Great, "K памятнику Петра I", in which the word "нерукотворный" was used in relation to the rock on which the monument stands [Фейнберг 1985: 577-591]. However, M. L. Gasparov pointed out that for any Russian reader the obligatory associations will be those with the image not made by hand (i. e. Acheiropoietos), whereas the associations with the mountain not made by hand can only be secondary [Гаспаров 2000].

${ }^{26}$ Although Gasparov expresses this change in terms of the reduction of both themes of time and space in Pushkin's poem in comparison with Horace and Derzhavin [Гаспаров 2000], the difference seems insignificant, which can be shown through the frequency of word-combinations referring to images of time and space: Pushkin uses 3 references to time and 4 to space (as well as 4 ethnonyms); Horace uses 4 denotations of time and 4 of space; Derzhavin uses 4 references to time and 3 to space (as well as 6 hydronyms and one oronym).

${ }^{27}$ An alternative explanation has been offered by Catriona Kelly, who argued that Pushkin was "also referring to the Pharos at Alexandria - and suggesting that his poetry would be the eighth wonder of the world" [Kelly 2001: 33]. 
world ("подлунном мире") and finally concludes with the widest image of the whole of Russia (“"по всей Руси великой”).

The image of space is developed in the list of ethnonyms (introduced by the initial reference to people in "народная тропа"), which take on the role played by toponyms in Horace's and Derzhavin's poems. However, in the change from toponymics to ethnonymics the accent is put not on space as such but on the people with their various languages (“всяк сущий в ней язык”) ${ }^{28}$. The perspective expands from the reference to the people's path, to monarchy, to the poets of the sublunary world and finally to the whole country and its different nations. The combination of the narrowing perspective of time and the simultaneously widening perspective of space creates a tension stressing the psychological, spiritual plane, which prevails in the poetic system of the text over its temporal-spatial scheme.

The material imagery ("тропа", “столп") gives way to the non-material, spiritual concepts which rule out the motif of egocentricity characteristic of the monument poetry tradition, going back to Horace's self-centredness [Nisbet, Rudd 2004: 365]. Although the concluding lines of both poems are addressed to the Muse and refer to divine inspiration ${ }^{29}$, the sentiments expressed in them differ radically. Horace asks his Muse to adhere to the ancient custom of reciprocity by granting him the laurel wreath of a victor; Pushkin, on the other hand, tells his Muse to obey the will of $\operatorname{God}^{30}$. Contrary to Horace, Pushkin explicitly advises his Muse to refrain from bestowing the laurel wreath (“обиды не страшась, не требуя венца"), in which he twice ironically depicted himself, as can be seen from his own drawings in two manuscripts [Вацуро 2000: 251, Эфрос 1933: 426]. The parallels between the ending of Horace's ode and the culminating stanza of "Памятник" suggest that Pushkin was challenging the tradition of monument poetry and refuting the proud words of Horace and Derzhavin with a warning to remain indifferent to slander and praise: "Хвалу и клевету приемли равнодушно". Pushkin is addressing his Muse with an admonition to pay no attention to those who cannot understand the great gift of poetry, with which both Horace and he had been endowed ("и не оспоривай глупца").

In Horace's and Derzhavin's odes the poets' merits were viewed as individual, personal, their Muse crowned herself, and therefore the development of imagery was horizontal and historical; in Pushkin's poem not only the question of personal achievement becomes irrelevant, but also the question of personal authorship; the mission of the poet is conceived as social, universal, spiritual, and correspondingly the development of imagery is vertical [Непомнящий 1987: 446]. As was aphoristi-

${ }^{28}$ It is not unlikely that Pushkin's innovation in shifting the emphasis on ethnic groups envisages further acts of translation and extends the transition from the Horatian motif of putting Greek songs to Latin metres to Pushkin's own works being translated into the new languages in his own country.

${ }^{29}$ Address to the Muse is indicated by the vocative case "Melpomene" in Horace and "o муза" in Pushkin.

30 “Веленью Божию, о муза, будь послушна". Rhymes in the last stanza remain as semantically significant as in the rest of the poem: 'послушна : равнодушно' establishes a correlation between being obedient to God's will and being indifferent to everybody else's judgment, be it those who have power or fools unworthy of attention. The rhymе "венца" : "глупца" stresses the idea that only fools seek earthly glory, an idea diametrically opposite to the message expressed in Horace's poem. 
cally stated by M. L. Gasparov, "Horace has in his scope of vision the poet and the Muse above him, Derzhavin — just the Muse, Pushkin — the Muse and God above her. Thus, the poetics of 'The Monument' is transformed as it transits from ancient literature to the literature of the Modern era" 31 .

$* * *$

Intertextuality drawing on the entirety of the poetic monument tradition becomes a structural component in the poems of the twentieth-century Russian writers who responded less to Horace than to Pushkin. While translations of Horace continued to be made, imitations entered into direct dialogue with Pushkin. Two faithful translations of Horace's ode were created by Valery Bryusov, an outstanding translator of classical poetry and one of the principal members of the Symbolist movement ${ }^{32}$. However, before translating Horace, Bryusov studied Pushkin's poetry and composed a poem based on the metaphor of verbal monument, "Памятник" (1912) [Степанов 1938].

The intertextuality of Bryusov's verse is manifested in its metrical similarity to Pushkin's poem ${ }^{33}$, as well as in his use of an epigraph from Horace. The phrase selected by Bryusov is not, however, the one chosen by Pushkin: in quoting, "Sume superbiam" ("Assume pride") as summary of the authorial intention of his poem he signals its distance from Pushkin's last stanza in particular. Unlike his major predecessors, Horace, Pushkin and Derzhavin, Bryusov declares the poetic nature of his monument, constructed entirely in verse: "Мой памятник стоит, из строф созвучных сложен" ${ }^{34}$. Instead of Horace's comparative (aere perennius) to affirm the immaterial nature of his monument, Bryusov uses a metaphor referring only to the verbal nature of his verse, which, unlike anything material, will never be subject to decay or decomposition (“распад певучих слов в грядущем не возможен”). This image of poetry with its intertextual reference to decay ${ }^{35}$ contrasts with its more traditional metaphorical representation as a "gift of propitious muses" ("подарок благосклонных муз"). But both tradition and imitation are broken in the image of poetry, highly innovative even for Symbolism, as "burning pages" ("горящие страницы”), depicted through adynaton, a trope present in all monument poems starting from Horace's predecessors.

31 “...У Горация в поле зрения поэт и над ним Муза, у Державина — одна Муза, у Пушкина - Муза и над нею Бог. Так преображается поэтика «Памятника», переходя из древней литературы в литературу нового времени" [Гаспаров 2000: 373].

${ }^{32}$ Bryusov's translations were created in 1913 (“Памятник я воздвиг меди нетленнеe") and in 1918 (“Вековечней воздвиг меди я памятник”). The text of Bryusov's poems is quoted from [Брюсов 1961].

${ }^{33}$ In spite of several points of metrical similarity, Georgii Shengeli came to the general conclusion that Pushkin's poem is metrically perfect whereas Bryusov's is lacking harmony, chaotic, disorganised, secondary, imitative [Шенгели 1918: 5-8, 23].

${ }^{34}$ A similar view on his poetic monument was formulated by Konstatin Batyushkov, in his letter of the 8th of July 1826 to A. G. Grevens after he had already fallen mentally ill ("Я памятник воздвиг огромный и чудесный, / Прославя вас в стихах: не знает смерти он!") [Батюшков 1886: 588-589]. Batyushkov's poem sounds like a parody of Derzhavin's verse but retains the characteristic features of the tradition: its egocentricity, driven to the utmost extreme, its chronotopical structure, the intertextuality (e. g. direct quotations from Derzhavin).

35 'Decay' is one of the meanings of the noun "situs", which is used in the word-combination "regali situ Pyramidum" in Horace's Ode 3.30 [West 2009: 261]. 
The metaphor of a poetic monument is revealed through the chronotopical structure of the poem, represented by means of a double perspective of both temporal and spatial imagery. The temporal characteristics of the verbal monument are reduced in Bryusov's poem to only three components (“в грядущем”, “слава наших дней”, "иных столетий слава"), starting and concluding with the future, and contrasting it with the present, thus retaining steady emphasis on eternal immortality.

The perspective of space, on the other hand, is widened and varied, as it is presented in a series of internally contrasted oppositions: the first pair "the huts of the poor" (“в каморке бедняка") and "the tsar's palace" (“во дворце царя") refers to the social scope of the metaphorical monument; the second pair, with its intertextual recollection of Horace's noisy Aufidus and silent Capitoline procession, extends the metaphor beyond Russia, contrasting "Ukrainian gardens" (“в сады Украйны”) with "the noise and sleep of the capital” (“в шум и яркий сон столицы”), in which a binary formula also consists of contextual antonyms ("шум", "сон"); the third pair stretches the metaphor to the exotic country (“к преддверьям Индии”) from a Russian river ("на берег Иртыша"); the fourth opposition contrasts an adverbial modifier referring to material reality ("повсюду") with the transcendental location ("у далеких грез"); the fifth pair juxtaposes the boundaries of sad homeland ("за переделы печальной родины") to other lands, represented through ethnonyms (“и немец, и француз / Покорно повторят мой стих осиротелый”) ${ }^{36}$, and to the obscure universal temple ("всемирный храм"), stressing the immaterial universal nature of the poetic monument. Unlike Derzhavin, who was content with achieving fame in his homeland, Bryusov shows the cosmopolitan nature of his poetry (characteristic of Symbolism), transgressing all national boundaries and widening the scope of perspective from Europe to India. It is possible that Bryusov borrows his allusion to a river ("на берег Иртыша") from Derzhavin; however, unlike the latter, he pairs this hydronym not with other names of rivers or seas but with the name of an exotic country, India, thus making them appear contextually identical.

Moreover, directly alluding to Pushkin's references to people and to monarchy, Bryusov transgresses the limits of social perspective, addressing his verse to the poor and the mighty (“в каморке бедняка", “во дворце царя"). Unlike his predecessors, Bryusov achieves the widest possible spatial perspective, transcending the space of fame beyond the limits of the real world into the realm of the imaginary, which is conquered by poetry as a means of communication. Poetry for Bryusov (and Symbolists) penetrates all worlds, the whole universe, the present and the future, the spatial, the social and the temporal.

Bryusov sees the value of his poetry and his poetic achievements in direct confrontation with Derzhavin and Pushkin. In contrast with the aims of his renowned predecessors, Derzhavin, who stresses the illuminating and the entertaining functions of his poetry, and Pushkin, alluding to the moral, ethical, spiritual aspect of poetic art, Bryusov prides himself exclusively on the aesthetic, literary, euphonious merits of his verse (“прославят гордо каждый стих", “и в новых звуках, зов проникнет за пределы"), as a Symbolist recognizing only the value of "art for art's sake". The supreme egocentricity or rather heliocentricity of Bryusov's "Памят-

${ }^{36}$ The image of the "orphaned verse" was viewed as a metaphorical image of text which is no longer subject to the author's will. It has been suggested that Bryusov foresaw the conception of the death of the author formulated by Roland Barthes [Жиляков 2010: 112]. 
ник", first signalled in his epigraph, is manifest in his transgressions of the monument tradition: he widens the scope of intertextuality, making subversive allusions not only to Horace, Pushkin and Derzhavin but also to the Bible (cf. his disguised quotation "Я есмь”). He flaunts his egocentricity by, unlike any of his predecessors in the tradition, including his own name into the text of his poem ("Ликуя, назовут меня - Валерий Брюсов"), as well as by renouncing the image of the Muse and substituting for it the image of the "Fame of other centuries" ("иных столетий Слава"). Personified Fame, perhaps acting as Virgil to Dante, takes the poet to the mysterious locus amoenus ("всемирный храм"), where his verbal monument, presented through a double chronotopical perspective, infinitely widening and transcending both universal and imaginary realms, is destined to loom for all time and all space.

The polemical nature of Bryusov's reception of the monument tradition was deepened in Vladimir Mayakovsky's ${ }^{37}$ intertextual dialogue with Pushkin's poem. In opposition to the views expressed in the collective manifesto of the Cubo-Futurists (Пощечина общественному вкусу, 1912), the poet's personal attitude to Pushkin, as revealed in "Юбилейное" (1924), ranges from joy at establishing a dialogue with him (expressed in the cordial address: "Извините, дорогой", as well as in the lines: "Мне приятно с вами, — / рад, / что вы у столика") to an open declaration of love (the opposition of contextual antonyms "alive" and "mummy" helps to convey a deep personal feeling: "Я люблю вас, / но живого, / а не мумию”) and the highest appreciation of his poetry (confirmed by the use of quotations from Евгений Онегин - "я сейчас же / утром должен быть уверен, / что с вами днем увижусь я"). "Юбилейное” develops the ekphrastic hypostasis of the monument, represented by Pushkin's statue, which is urged by the lyrical hero to leave its pedestal and join in a poetic dialogue ${ }^{38}$. The idea of poetic proximity is developed by the lyrical hero envisaging the construction of his own monument ("Мне бы / памятник при жизни / полагается по чину"), implying not only the material statue but also the metaphorical eternal monument personified in the poet's writing ("После смерти / нам / стоять почти что рядом: вы на Пе, / а я / на Эм"; “У меня, / да и у вас, / в запасе вечность"). However an intertextual allusion to the whole monument poetry tradition can be discerned in a highly negative attitude of the lyrical hero to the posthumous fame embodied in a statue ${ }^{39}$, which is in full keeping with the Futurists' rejection of the value of any canon, including literary.

Mayakovsky's denial of all traditions paradoxically involves him into dialogue with verbal monument poetry in his unfinished poem Во весь голос (1929-1930).

${ }^{37}$ The texts of Mayakovsky's poems are quoted from [Маяковский 1960].

${ }^{38}$ Contrary to literary canons, manifested for instance in Pushkin's Каменный гость, in which the statue's handshake brings death to the human being, in "Юбилейное" it is the poet himself who shakes the statue's hand in order to establish relations of mutual closeness and equality. The image of a statue represented in Mayakovsky's text has nothing in common with the image of a harmful, fatal, injurious statue, created in Pushkin's own poetry (Медньій всадник, Каменный гость, Золотой петушок) [Якобсон 1987].

${ }^{39}$ Mayakovsky's response to statues (manifested in his lines “'Заложил бы динамиту — нука, дрызнь!") follows Pushkin's attitude to verbal versus material monuments, expressed in his letter of 29 May 1834: "Скопляю материалы — привожу в порядок — и вдруг вылью медный памятник, которого нельзя будет перетаскивать с одного конца города на другой...”, in which the poet refers to his own work on the history of Peter the Great [Якобсон 1987: 169]. 
Like most monument texts, Во весь голос constitutes the poet's testament, expressing his views on poetry, his time and himself, i. e. the role of the poet in space and time. Intertextuality, the key characteristic of verbal monument poetry, is evident in the poet's treatment of the motif of personal immortality. Mayakovsky is the first poet who, contrary to his predecessors, presents this topical theme in a negative light: his own verse is compared to "a nameless soldier" who is destined to die (“Умри, мой стих, / умри, как рядовой, / как безымянные / на штурмах мерли наши!"). The mortality (or immortality) of the poet's own verse ("Стихи стоят / свинцово-тяжело, / готовые и к смерти / и к бессмертной славе”) is opposed to the poetic fame of unnamed poetic genius ("Пускай за гениями / безутешною вдовой / плетется слава / в похоронном марше") and seems undesirable to the poet, as it is doomed to the pathetic fate of an inconsolable widow.

The theme of poetic immortality is given an alternative interpretation if poetry performs its true function of contributing to the construction of the ideal society. Like all monument poems, Во весь голос unfolds the metaphor of the verbal monument in a temporal-spatial perspective ("Мой стих дойдет / через хребты веков / и через головы / поэтов и правительств"), in which neither time (“хребты веков"), nor space (“через головы / поэтов и правительств") is viewed as a challenge for his poetic art. Although the reference to poets and governments echoes the juxtaposition of poets and monarchs in both Pushkin's and Derzhavin's poetry, Mayakovsky sees no difference between the two and foresees his future fame irrespective of both.

The theme of poetic fame and immortality is intertwined with the theme of Rome (“Мой стих / трудом / громаду лет прорвет / и явится / весомо, / грубо, / зримо, / как в наши дни / вошел водопровод, / сработанный / еще рабами Рима") and is given a new chronotopical dimension, referring to the past ("Рим"), present (“наши дни") and future (“громада лет"). The Roman theme creates a context for the appearance of the Horatian theme of exegi monumentum, which is categorically refuted through the abrupt tone of the lines: "Мне наплевать на бронзы многопудье, / мне наплевать на мраморную слизь". In his rejection of posthumous fame (“Сочтемся славою - ведь мы свои же люди”) Mayakovsky echoes Horace's idea of immortality being measured by the existence of Rome with its ceremonial processions, and Derzhavin's idea of immortality determined by respect for the Slavonic nation. Mayakovsky's fame and immortality is measured by the existence of socialism as an ideal world-order (“пускай нам общим памятником будет построенный в боях социализм") and thus diverges from Pushkin, who assessed his fame through references to poets and therefore poetry ("И славен буду я, доколь в подлунном мире / Жив будет хоть один пиит”). The material (ekphrastic) representations of the monument, denoted with the help of two highly expressive word-combinations, containing an oxymoron ("мраморная слизь") and a hapax legomenon combined with a Horatian lexeme "aere" (“бронзы многопудье"), are given as a false refutation of the tradition but in effect precisely follow it (starting from Horace material objects were rejected as challenges to verbal monuments).

Ekphrastic representations are contrasted with the immaterial monument, though not verbal or poetic, but "ideological" (“социализм"), constructed with the help of the immortal weapon of poetry. The polemical nature of the opposition of the desired and the rejected monument is underlined by the semantics of its attributes: 
the participle "построенный" with the meaning "constructed" (cf. "exegi" in Horace, "я памятник себе воздвиг" in Pushkin and Derzhavin) and the adjective "общий" bring into prominence the shared nature of the poet's monument as opposed to the individual fame of his poetic predecessors. The egocentricity of the preceding monument poems is intertextually considered and consciously renounced. The metaphor of the shared immaterial monument is used to reject the idea of creating any monument, albeit verbal or poetic.

The tradition of the verbal monument is polemically treated by Iosif Brodsky in his poem “Я памятник воздвиг себе иной..." $(1962)^{40}$. The change of the quotation through the inclusion of the word "иной" elevates the initial line to the status of a poetic declaration: the allusion to the tradition signifies that Brodsky's monument will be different from his predecessors'. The primary distinction consists in the ambiguity of the representation of the poet's monument, which is gradually revealed through the chronotopical perspective of the poem.

The spatial perspective is unravelled by Brodsky differently from all verbal monument poets starting from Horace: it occupies the whole area of the poem and is consecutively intertwined with the temporal perspective: "К постыдному столетию - спиной". The image of time, which was almost invariably (with the exception of Pushkin) widened in the preceding monument tradition to the realms of eternity, becomes reduced in Brodsky's poem to the single highly expressive image of a "shameful century". The position of the monument, turning its back on the shameful century and revealing its contempt, contains the first hint of the monument being alive. The notion of the living monument is revealed in its proud audacious posture ("И грудь - велосипедным колесом") and its disgust for the "ocean of half-truths" (“А ягодицы - к морю полуправд"). The reference to the metaphoric "ocean" as well as the motif of contempt allude to Derzhavin's "Пaмятник", in which the poet's fame was presented in terms of hydronymic references, and a veiled allusion to Pushkin's final stanza. Pushkin's metaphoric image of poetic elevation ("Вознесся выше он") is intertextually echoed in Brodsky's image of height, signified by the use of the same verb ("вознесла") but cast into the oxymoronic context of "усталость" ("Мне высота и поза та мила. / Меня туда усталость вознесла"). The "defamiliarisation" (остранение) through a paradoxical context creates the expectation of self-irony, which is confirmed by the use of low vocabulary, mostly referring to parts of the body (“лицо", "спина", “грудь", “ягодицы"), as if dissecting and thus destroying the traditionally elevated image of poetic monument.

The traditional antithesis of the high and the low, the poet and the crowd, is reflected in the opposition of the unnamed accusers, shown through a series of destructive actions, and the lyrical hero, insisting on his right to remain true to his image: “я облик свой не стану изменять". The same opposition is revealed in contrasting terms: the poet and the children ("на радость детворе"), for whom the poet will be forever pleasing (another allusion to Pushkin's “любезен народу”).

${ }^{40}$ The text of Brodsky's poem is quoted from [Бродский 2001]. Brodsky composed another poem with the title "Aere perennius", containing a veiled allusion to Horace's Ode to Melpomene. Apart from the title establishing a dialogue with Horace and Pushkin, the poetic style and content of Brodsky's poem is different from those of Horace, Derzhavin and Pushkin and does not use the metaphor of a poetic monument. 
An additional intertextual reference to the monument tradition, the poet's address to the Muse, is placed in a low context of mock familiarity: “Ты, Муза, не вини меня за то. / Рассудок мой теперь, как решето, / а не богами налитый сосуд”. The mocking mixture of the high and the low is continued through the opposition of "a sacred vessel filled by gods" and "a sieve", used in the description of the poet's mind and raising the question whether an ironic treatment of the motif of the poet's egocentricity is intended.

The mixture of registers creates the context for a synchronic presence in the image of the monument of three different hypostases: the monument is simultaneously treated as the metaphoric, the ekphrastic and the living. The focal point is revealed through the whole spectrum of destructive actions ("Пускай меня низвергнут и снесут, / пускай в самоуправстве обвинят, / пускай меня разрушат, расчленят"), applicable to all kinds of monuments, from the metaphoric which can be "overthrown", to the ekphrastic which can be "knocked down", to a living person who can be accused of voluntarism, especially by those in power, or indeed "dismembered". Diverse activities centred on the different hypostases of the poet's monument create a sense of the universal hostility of the surrounding world to any manifestation of poetic gift and individuality.

The process of destruction is resolved in the final concrete embodiment of the monument in its ekphrastic representation ("В стране большой, на радость детвоpe / из гипсового бюста во дворе / сквозь белые незрячие глаза / струей воды ударю в небеса") ${ }^{41}$. The image of the metaphoric monument develops through the image of a living monument, which had undergone the process of demolition, to the image of a fragile non-durable short-lived "alabaster bust". The ekphrastic representation of the monument is characterised through a varied spatial perspective (from "the big country" through "the yard" to "heavens") and temporal range (the only three finite verbal forms in the poem express the idea of elevation and expand from the past ("воздвиг", "вознесла") to the future ("ударю в небеса"), intertextually alluding to the whole tradition behind the initial unchangeable image ("я облик свой не стану изменять"). The chronotopical characteristics of Brodsky's ekphrastic monument are reduced by a "shameful century" to a yard in a big country but its height grows into heaven. The ambiguity of the image of the poetic monument unfolded through the variety of spatial and temporal perspectives can be interpreted as evidence of the decanonisation of the tradition.

Rejection of the poetic tradition, resulting in its final destruction, is represented by Alexey Purin's “Памятник” (2004) ${ }^{42}$, which provides an intertextual denial not only to the images and but to their verbal expression in Pushkin's poem. Purin's poem starts with a meaningful distortion of Pushkin's initial lines (“Я памятник

${ }^{41}$ In Brodsky's poem blindness ("незрячие глаза"), providing through a conscious choice a defence against a "shameful century", can be interpreted as an allusion to the ancient sculpture, developed in the poem "Бюст Тиберия" ("Приветствую тебя две тыщи лет спустя"), in which the poet is addressing the Emperor's bust and constructing a monument of shame and disdain. However, a more suitable understanding of the motif of blindness could be as an equivalent of prophetic insight and poetic revelation (cf. "Слепота оказывается более зрячей, потому что хранит во тьме сознания образы прошлого" [Ямпольский 1993: 8], which would establish an associative link with the epic poet par excellence and a famous blind prophet of ancient Greek mythology).

${ }^{42}$ The text of Alexey Purin's poem is quoted from [Пурин 2005]. 
себе воздвиг нерукотворный”), stating that his monument is hardly perceptible by both the majority and individuals ("Я памятник воздвиг - едва ли ощутимый / для вкуса большинства и спеси единиц"). Pushkin's metaphor of the monument not made by hands, and therefore eternal, is developed into a metaphor of something ephemeral and illusory ("Живые сыновья, увидев этот мнимый / кумир, не прослезят взыскующих зениц"). The intertextual motif of fame is only faintly echoed in the description of the process of poetic creation but not of its result ("не ведая о том, сколь сладостно и славно / переплавлялась боль на стиховом огне"). The outcome of the poet's labour is a "phantom eidolon" ("мнимый кумир"), which makes it clear that Purin is describing a metaphorical monument, though humble and imperceptible, bringing joy to the creator through its creation.

Polysemy in Purin's poem is used as a powerful intertextual means of generating antonymous meanings: in Pushkin's poem (“Слух обо мне пройдет по всей Руси великой") the noun "слух" is used in the general meaning of "talk, report, word', and the verb "проходить" in the meaning 'spread, reach', as it is followed by the adverbial modifier of place (name of the country), so the whole line means "the word about me will spread"; in Purin's poem the same line ("Слух обо мне пройдет") is used with precisely the opposite meaning: "the rumour of me will pass". The contrast in meaning is revealed by the absence of adverbial modifiers of place, instead of which the poet supplies two comparisons ("как дождь проходит летний, / как с тополей летит их безнадежный пух"), underlining the idea of transitoriness; as well as two metaphors ("отсылкой в словаре, недостоверной сплетней"), in which the contextual synonym of the word meaning 'rumour' becomes the word "gossip" ('сплетней'). Thus, Pushkin's notion of "the word" (logos), triumphing over eidolon ${ }^{43}$, becomes travestied and lowered to the notion of "rumour, gossip", creating "phantom eidolons". The polysemy of the noun "слух" which becomes one of the key intertextual concepts in Purin's poem is played upon in the conclusion of the stanza ("И незачем ему неволить чей-то слух"), where it refers to aural perception, the ear, implying the idea of rumour being whispered into somebody's ear and downgrading the image to a lower stylistic rank. The idea of poetic immortality is given a negative intertextual retort in Purin's poem: Pushkin's statement "Нет, весь я не умру", going back to the Horatian "non omnis moriar", is denied ("Умру. И все умрет...") and intertextually confirms Brodsky's lines "Мои слова, я думаю, умрут" (1963), in which a glimpse of a faint hope was expressed.

It is possible that the intertextuality of Purin's poem goes back not only to Pushkin's poem but also to the poem of his younger contemporary Evgenii Baratynsky (1828): "Мой дар убог, и голос мой не громок, / Но я живу, и на земли мое / Кому-нибудь любезно бытие: / Его найдет далекий мой потомок / В моих стихах; как знать? душа моя / Окажется с душой его в сношеньи, / И как нашел я друга в поколеньи, / Читателя найду в потомстве я" [Баратынский 1936: 163]. The metaphor of verbal monument is irrelevant for Baratynsky's poem, the only motif reminiscent of the monument tradition being the appreciation of the poet's verse in generations to come. However the value of Baratynsky's “Мой дар убог, и голос мой негромок" for the present article consists in an intertextual reference to its

${ }^{43}$ The eidolon is represented in Pushkin's poem by the Alexandrian column, over which the poet's verbal monument triumphs: “Так logos (слово) побеждает eidolon (кумир) и кумиропоклонство" [Якобсон 1987: 165]. 
title in a poem probably composed by the Decembrist poet Gavriil Batenkov, "Non exegi monumentum" (1856), and representing a new form of anti-panegyric, deeply personal poetry with an accent on biographical detail: "Себе я не воздвиг литого монумента, / Который бы затмил великость пирамид; / Неясный облик мой изустная легенда / В народной памяти едва ли сохранит. / Но весь я не умру: неведомый потомок / В пыли минувшего разыщет стертый след/ И скажет: 'Жил поэт, чей голос был негромок, / А все дошел до нас сквозь толщу многих лет" "44. The genre of Batenkov's poem was described as an "anti-pamiatnik" [Илюшин 1978: 54-56]; however, it has been suggested that its origin is dubious and that it may have been composed much later than is usually stated [Шапир 1997; 1998]. The ways in which the traditional motifs of monument poetry are treated in "Non exegi monumentum" seem extraordinarily ahead of its time and support Maxim Shapir's hypothesis.

Intertextuality is the indispensible key for interpreting Purin's poem, every line of which echoes one (or several) of the monument texts: Horace is referred to in the concluding stanza mentioning the Capitoline priest (“Капитолийский жрец"); Derzhavin's proud ethnonym (“славянов род") is echoed in the derogatory allusion to the same ethnonym but supplied with the epithet "no longer loved" ("род славян постылый"); Derzhavin's allusion to universal fame in the memory of coming generations (“всяк будет помнить") is rejected in the negative statement ("не вспомнят обо мне"); Pushkin's reference to the proud grandchildren of the Slavs ("гордый внук") is denied in the negation ("И внуки никогда, а правнуки - подавно"). The address to the Muse travesties both the semantic and the phonetic structure of the monument tradition: "о, Муза", becomes "Но, Муза"; the Muse is not asked to crown, as in Horace and Derzhavin, nor is she asked to be indifferent to people's slander and praise, as in Pushkin, but to estimate the spider-like effort of the poet to contest the glory of emptiness ("'оцени - с какой паучьей силой / противилось перо величью пустоты"). If for the preceding poets the challenges of their verbal monuments were time and space, in Purin's poem it is nothing but emptiness, whose glory the poet can only attempt to conquer by his gift. The accumulation of allusions and quotations from the tradition of monument poetry and the mixture in Purin's idiolect of low words and high vocabulary, mostly going back to his great predecessors, bring his poem close to bricolage: the meaning of his text is shaped through references to the poems of the preceding monument tradition.

$$
* * *
$$

Like bricolage, parody is directed at a certain text, separating it from the original literary corpus, dividing it into fragments and destroying it as a system [Тынянов 1977]. The intertextuality of Vladislav Khodasevich's poem, “Павлович! С посошком ${ }^{45}$, бродячею каликой” $(1921)^{46}$ depends on only two quotations from

${ }^{44}$ Batenkov's poem is quoted from [Фризман 1980].

45 The word "staff" ('посох') in its diminutive form ('посошок') in Khodasevich's poem could contain an intertextual reference to Osip Mandelstam's poem ("Посох мой, моя свобода — / Сердцевина бытия"), inspired by Petr Chaadaev [Аверинцев 1996: 226-230].

${ }^{46}$ The text of Khodasevich's poem is quoted from [Ходасевич 1997]. The poem is addressed to N. A. Pavlovich (1895-1980), a poet, translator, and literary critic. 
Pushkin ("по всей Руси великой” and “Александрийского столпа"47). However Khodasevich's text, with its Horatian epigraph, "Exegi monumentum", is clearly aimed at establishing a dialogue with Pushkin's poem, in which the same epigraph is used ${ }^{48}$. It is related to the poetic monument tradition only through references to Pushkin, as the word "monument" is not mentioned anywhere except in the epigraph. The parodic nature of Khodasevich's poem is signalled by the presence of formal markers, e. g. a playful beginning, containing an informal address, inviting the reader to join in an idiosyncratically post-modern literary game. A mixture of low ("И столько мне пришлют яиц") and high registers (“бродячею каликой, Руси великой, Александрийского столпа"), mostly borrowed as quotations from Pushkin's poem, creates a comic effect for the sake of entertainment.

The chronotopical structure of the parody is reduced to the vividly delineated topical constituent (“от финских скал вплоть до донских станиц”, “по всей Руси великой”, “на площади Урицкой”), in which a reference to Russia is contrasted with the reference to the square named after a famous revolutionary, an organiser of the red terror, the Cheka chairman ${ }^{49}$. In keeping with the monument tradition, the toponyms occurring in the text denote places geographically distant from each other. Like Bryusov's poem, Khodasevich's parody contains references not only to Russia to but also to Ukraine ("донских станиц", whereas the adjective "финских" could contain a veiled allusion to Pushkin's inclusion of “финн” into his list of ethnonyms).

The motif of poetic egocentricity, inherited from the verbal monument tradition, is underlined in Khodasevich's parody both lexically ("поклонников толпа") and grammatically with the help of personal and possessive pronouns ("мои стихи", "мне пришлют", "поможет мне") ${ }^{50}$. Unlike all authors of monument poems, Khodasevich does not wish to enumerate his poetic achievements, but other memories of the tradition (i. e. the chronotopical structure, intertextuality, egocentricity) are retained in his parody ${ }^{51}$.

The function of entertainment prevails in one of the latest humorous versions of Pushkin's poem by Igor Fedorov (2004): “Памятник себе воздвиг я, / не прикладывая рук. / Только финн и ныне дикий / друг степей — чего-то вдруг / стороной его обходят. / Ладно б финн, едрена мать! / Но тунгус - уж ты-то,

47 “То, выглянув в окно, уж не найдет Белицкий/ Александрийского столпа" (E. Ia. Belitskii was a writer, a psychiatrist and the owner of the Petersburg publishing house Epoch).

${ }^{48}$ Pushkin's poetry was the object of Khodasevich's scholarly studies, published in [Ходасевич $1924 ; 1937 ; 1997]$.

${ }^{49}$ In 1918, Palace Square in Petrograd (Дворцовая площадь) was renamed after the chairman of the Petrograd Cheka, M. S. Uritsky. The historical name was returned to the square in 1945.

${ }^{50}$ The motif of egocentricity is developed in connection with the themes of loneliness and age and denounced in Khodasevich's роет "Перед зеркалом", which is introduced with the epigraph from Dante's Inferno, "Nel mezzo del cammin di nostra vita".

${ }^{51}$ Khodasevich composed another Monument poem (1928): "В России новой, но великой, / Поставят идол мой двуликий / О перекрестке двух дорог, / Где время, ветер и песок". Тhe poem is independent of Horace's ode and contains an ekphrastic representation of the monument tradition: the two-faced idol, resembling Janus, is positioned in a meaningful location in time and space: in Russia on a crossroads, uniting the temporal scope of the present and the past with the spatial boundary between the two worlds. The chronotopical perspective gives a reference to the tradition of monument poetry through time (cf. Horace's "flight of time", fuga temporum) and wind (cf. Horace's Aquilo). 
вроде, / свой! Ты ж должен понимать! / Для кого я так старался, / водку пил, не досыпал, / для кого я надрывался? / для кого стихи писал? / Ты же свой российский парень, / хоть, быть может, и тунгус... / Осетин, карел, татарин / или даже белорус — / все равно, сюда идите — / скопом иль по одному. / Хоть бы стежку протопчите / к монументу моему" [Федоров 2005]. The object of parody is not the tradition as a whole but the most representative text, quotations and allusions to which are easily recognisable but distorted and lowered: "нерукотворный" is turned into "не прикладывая рук”, “народная тропа” into “стежка”, “ныне дикий” is united with “друг степей”. Pushkin's ethnonyms (финн, тунгус) become the object of word-play. The comic effect is achieved by the high poetic vocabulary of Pushkin's quotations being consistently "defamiliarised or estranged", to use the term of the Russian formalists, by the humorous parodic context.

Parody signals the beginning of the process of textual decanonisation and at the same time continues its development, showing that the text remains meaningful for a contemporary audience (as Yuri Tynyanov wrote, parodies are never directed at half-forgotten phenomena) [Тынянов 1977]. In post-modernism, literary parodies of Pushkin's famous poem continue to appear and are signified by the use of the Horatian epigraph "Exegi monumentum", as in Boris Zakhoder's "Памятник”. The allusion to Horace, underlined by Zakhoder's inclusion of the Roman poet's name (Horatius), is, however, misleading, as his "Памятник" is directed at the whole tradition rather than at a single text. The reference to the verbal monument tradition is shown by its polemical beginning, where the reader is addressed with a rhetorical question aimed at establishing friendly relations ${ }^{52}$ : “Сказать ли правду?" "Памятников - нет. Ни рукотворных, ни нерукотворных". The negative answer challenges Pushkin's famous line, whereas the continuation aims at Derzhavin (cf. Derzhavin's “Века времен в своем стремленьи / Уносит все дела людей / И топит в пропасти забвенья / Народы, царства и царей” and Zakhoder's lines: “Настанет срок - увы, сотрется след / Всех наших дел - и славных, и позорных... / След океанов и массивов горных, / Самой Земли, ее сестер - планет...”). Zakhoder's parody can be viewed as a pastiche, in which every line aims at one of the monument poems as an object of travesty.

In Zakhoder's poem the theme of earthly transience, characteristic of the verbal monument tradition, is given a humorous treatment (“Сотрется след побед и прочих бед, / След вдохновений и трудов упорных, / Черты царей на серебре монет / И надписи в общественных уборных").The motif of fame only occurs in the adjective "славный", which is put in direct proximity to its antonym "позорный" and applied to deeds doomed to oblivion, creating the impression that from the perspective of eternity fame is indistinguishable from shame. The highest achievements of human inspiration and hard work, implying the composition of poetry, are regarded as identical to graffiti in public toilets and both are treated as metaphors for "verbal monuments". The consolation for the poet becomes not his eternal glory and universal fame but his own smile (“Сотрется след вселенной, / Где мы с тобой сумели - между строк - / Прочесть усмешку вечности. Мгновенной. / Сотрется след... Но не горюй, поэт! / Ты тоже усмехнулся - ей в ответ”).The reference to the key concepts of monument poetry: "universe" (“след вселенной”)

${ }^{52}$ The text of Zakhoder's poem is quoted from [Заходер 1996]. 
and "eternity" ("усмешка вечности") outlines the chronotopical scope of Zakhoder's poem, but both temporal and spatial co-ordinates are defamiliarised by an oxymoronic context: the universe only leaves a trace which is destined to obliteration; eternity is reduced to a momentary state, also doomed to disappearance. Relations of equality are established between the fates of the poet and of the universe: both are doomed to disappear, but each treats the other with irony and a smile. Thus, the idea of the poet's immortality is reduced to that of the momentary existence of the poet, the universe and eternity, which makes any kind of verbal monument irrelevant and completes the decanonisation of the tradition.

$$
* * *
$$

In parody the process of decanonising the poetic monument tradition is taken to a new level, showing its relevance for modern culture. The tradition based on the verbal monument metaphor, transformed rather than destroyed by a parody, is an open system and its parodic (or canonical) treatment is likely to be continued in postmodernist literature, "defamiliarising" it through the prism of travesty, as in Brodsky's poem, or irony, as in Khodasevich's or Zakhoder's parodies.

Parodies refute the inherent features of verbal monument poems, such as intertextuality, "egocentricity" and the unfolding of the basic metaphor through spatial and temporal perspectives. The postmodernist literary game, created by Khodasevich's parody, rejects the temporal perspective altogether, though it retains memories of the monument tradition through intertextuality, egocentricity and a spatial constituent. The reduction of the chronotopical structure undermines the nature of the metaphor: the poetic monument disappears from Khodasevich's poem altogether. The structural features of monument poetry (the poet's immortality, egocentricity) are stylistically lowered and semantically reversed through oxymoronic contexts in Zakhoder's "Памятник", where the metaphor of a poetic monument, elucidated through the chronotopical structure, is reduced to total oblivion in time and space.

Unlike Zakhoder's parody directed at the whole tradition and Khodasevich's dialogue with Pushkin, Brodsky's poem continues the process of decanonisation by the ambiguity of representing the poet's monument through the temporal-spatial perspective from the metaphoric, through the living, to the ekphrastic. Decanonisation is completed in Purin's "Памятник", in which the chronotopical representation of the metaphoric monument unfolds in the direction of the ephemeral, illusory, imperceptible, and supplies an intertextual refutation of the verbal expressions of his great predecessors, which brings the structure of his poem close to bricolage.

A polemical response to the verbal monument tradition is deepened in Bryusov's treatment of the metaphor, which is revealed in direct dialogue with Derzhavin and Pushkin. The supreme egocentricity of the poet is manifested in unfolding the metaphor through the widest possible spatial and temporal perspectives, transcending the space of fame into the realm of the imaginary. The chronotopical perspective is unfolded beyond all limits in either time or space by Mayakovsky, who polemically engages the metaphor of the shared immaterial "ideological" monument in order to renounce the idea of creating any personal monuments, whether verbal or ekphrastic.

Polemic responses, parodies and travesties are invariably directed at Pushkin's poem, demonstrating its continuous presence in the collective memory of Russianspeaking nations. The ongoing dialogue with Pushkin can be accounted for by the 
desire of successive generations of poets to measure themselves against his genius. However the idea of a parodic treatment of the poetic monument tradition belongs to Pushkin himself (cf. a draft of the thirty-ninth stanza of the second chapter of Евгений Онегин) $)^{53}$. Imitation of Pushkin is certainly the source of the immense popularity of Horace's ode in Russia, which is incomparable with its fate in other literary traditions. Although the canonisation of the verbal monument metaphor was completed in Pushkin's famous poem, it paradoxically contains the first signs of the decanonisation of the tradition. The combination of the narrowing perspective of time and the widening perspective of space creates a tension, which brings into prominence the psychological, spiritual plane overshadowing the expansion of the metaphor. The individual fame of the poet becomes irrelevant, which results in his renunciation of the crown (i. e. the monument) in direct polemics with the tradition.

Pushkin's challenge to the canonical treatment of the metaphor is directed not only at Horace's but also at Derzhavin's poem, with which the canonization of the verbal monument tradition began in Russian literature. In Derzhavin's ode, which presents the biography of the poet in terms of temporal and toponymic characteristics, the location of his verbal monument is defined through expanding chronotopical coordinates. The expansion of both linear and reverse perspectives creates the "perceptive perspective", stressing the individual achievement and enhancing the motif of the poet's egocentricity.

The attitude to time and space as challenges to verbal monuments, inherited by Derzhavin from Horace, determines the chronotopical structure of all verbal monument texts. The metaphor of a poetic monument in Horace's ode, making a powerful and uncontested claim for poetry as a more enduring monument than anything made of material substance, is perceived in terms of double reverse perspective, widening through the temporal perspective of eternity and the spatial perspective of the entire poetic universe. Its historical distance accounts for the inclusion of Horace's ode into the high canon, though his ode glorifying the poet through his achievement could only have become the subject for parody today.

\section{Литература}

Аверинцев - Аверинцев С. С. Судьба и весть Осипа Мандельштама // Аверинцев С. С. Поэты. М.: Школа «Языки русской культуры», 1996. С. 189-273.

Алексеев 1967 - Алексеев М. П. Стихотворение А. С. Пушкина «Я памятник себе воздвиг...». (Проблемы его изучения). Л.: Наука, 1967.

Баратынский 1936 - Баратынский Е. А. Полн. собр. стихотворений: В 2 т. Т. 1. Л.: Сов. писатель, 1936.

Батюшков 1886 - Сочинения К. Н. Батюшкова / Изд. П. Н. Батюшковым: со ст. о жизни и соч. К. Н. Батюшкова, написанной Л. Н. Майковым, и прим., сост. им же и В. И. Саитовым. Т. 3. СПб.: Тип. Котомина, 1886.

Бахтин 1975 - Бахтин М. М. Формы времени и хронотопа в романе. Очерки по исторической поэтике // Бахтин М. М. Вопросы литературы и эстетики. СПб.: М.: Худ. лит., 1975. C. 234-407.

53 “Быть может, этот стих небрежный / Переживет мой век мятежный. / Могу ль воскликнуть, <о друзья> / 'Exegi monumentum я' " [Пушкин 1935: 693-694]. For a discussion of Pushkin's draft see [Алексеев 1967: 136-138]. 
Бродский 2001 - Сочинения Иосифа Бродского: В 7 т. Т. 1. СПб.: Изд-во Пушкинского фонда, 2001.

Брюсов 1961 - Брюсов В. Я. Стихотворения и поэмы. Л.: Сов. писатель, 1961.

Вацуро 2000 - Bаџуро В. Э. Пушкинская пора. СПб.: Академический проект, 2000.

Веселовский 1989 - Веселовский А. Н. Историческая поэтика. М.: Высшая школа, 1989.

Войтехович $2000-$ - Войтехович Р. С. О горацианском претексте «Я памятник себе воздвиг нерукотворный...» // Пушкинские чтения в Тарту. [Т.] 2. Материалы междунар. науч. конф. 18-20 сентября 1998 г. / [Под ред. Л. Киселевой]. Tарту: Tartu Ülicooli Kirjastus, 2000. C. 228-234.

Гаспаров 2000 - Гаспаров М. Л. Топика и композиция гимнов Горация // Гаспаров М. Л. Об античной поэзии: Поэты. Поэтика. Риторика. СПб.: Азбука, 2000. С. 323-373.

Державин 1957 - Державин Г. Р. Стихотворения. Л.: Сов. писатель, 1957.

Живов 1996 - Живов В. М. Государственный миф в эпоху Просвещения и его разрушение в России конца XVIII века // Лотман Ю. М. Живов В. М., Аверинцев С. С. и др. Из истории русской культуры. Т. 4: XVIII - начало XIX века. М.: Языки русской культуры, 1996. С. 657-684.

Жиляков 2010 - Жиляков С. В. Жанровая традиция стихотворения-«Памятника» в русской поэзии XVIII-XX вв.: Дис. ... канд. филол. наук / Елец. гос. ун-т им. И. А. Бунина. Елец, 2010.

Заходер 1996 - Заходер Б. В. Почти посмертное. М.: ГКЦМ Дом Высоцкого; ИЦ «Вагант», 1996.

Илюшин 1978 - Илюшин А. А. Поэзия декабриста Г. С. Батенькова. М.: МГУ, 1978.

Клейн 2004 - Клейн И. Поэт-самохвал: «Памятник» Державина и статус поэта в России XVIII века / Пер. с нем. Е. Матусовой // Новое литературное обозрение. № 65. 2004. C. $148-169$.

Ломоносов 1986 - Ломоносов М. В. Избр. произведения. Л.: Сов. писатель, 1986.

Ломоносов 1959 - Ломоносов М. В. Полн. собр. соч. Т. 8: Поэзия, ораторская проза, надписи, 1732-1764. М.; Л.: Изд-во АН СССР, 1959.

Маяковский 1960 - Маяковский В. В. Избр. произведения: В 2 т. М.: Гос. изд-во худ. лит., 1960.

Мусорина $2000-$ Мусорина Л. А. Подражания тридцатой оде Горация в русской литературе // Наука. Университет. 2000: Материалы Первой науч. конф. Новосибирск: Новый сибирский ун-т, 2000. С. 86-90.

Непомнящий 1987 - Непомнящий $B$. С. Поэзия и судьба. Над страницами духовной биографии Пушкина. М.: Сов. писатель, 1987.

Песков 1984 - Песков А. М. О поэзии Ломоносова и о поэзии Державина // Ломоносов М. В., Державин Г. Р. Избранное. М.: Правда, 1984. С. 3-18.

Пумпянский 1977 - Пумпянский Л. В. Об оде А. Пушкина «Памятник» // Вопросы литературы. 1977. № 8. С. 76-88.

Пурин 2005 - Сочинения Алексея Пурина: Архаика/Евразия. СПб.: Звезда, 2005.

Пушкин 1935 - [Пушкин А. С.]. Рукою Пушкина: Несобранные и неопубликованные тексты / Подгот. к печати и коммент. М. А. Цявловский, Л. Б. Модзалевский, Т. Г. Зенгер. М.; Л.: Academia, 1935.

Пушкин 1962-1965 - Пушикин А. С. Полн. собр. соч.: В 10 т. 3-е изд. М.: Наука, 19621965.

Раушенбах 1986 - Раушенбах Б. В. Системы перспективы в изобразительном искусстве. М.: Наука, 1986. 
Степанов 1938 - Степанов Н. Л. В. Я. Брюсов в работе над Пушкиным // Литературный архив: Материалы по истории литературы и общественного движения / Под ред. С. Д. Балухатого и др. М., Л.: Изд-во АН СССР, 1938. С. 302-351.

Сурат 2009 - Сурат И. З. Мандельштам и Пушкин. М.: ИМЛИ РАН, 2009.

Тынянов 1977 - Тынянов Ю. Н. О пародии // Тынянов Ю. Н. Поэтика. История литературы. Кино. М.: Наука, 1977. С. 284-309.

Федоров 2005 - Федоров И. В. Стихи Игоря Федорова. М.: Изд-во Н. Филимонова, 2005. Фейнберг 1985 - Фейнберг И. Л. Читая тетради Пушкина. М.: Сов. писатель, 1985.

Фризман 1980 - Высокое стремленье: Лирика декабристов / Сост., коммент. и вступ. ст. Л. Г. Фризмана. М.: Дет. лит., 1980.

Ходасевич 1924 - Ходасевич В. Ф. Поэтическое хозяйство Пушкина. Л.: Мысль, 1924.

Ходасевич 1937 - Ходасевич В. Ф. О Пушкине. Берлин: Петрополис, 1937.

Ходасевич 1997 - Ходасевич В.Ф. Собр. соч.: В 4 т. М.: Согласие, 1997.

Шапир 1997 - Шапир М. И. Феномен Батенькова и проблема мистификации (Лингвостиховедческий аспект. 1-2)// Philologica. Т. 4. № 8-10. 1997. С. 85-144.

Шапир 1998 - Шапир М. И. Феномен Батенькова и проблема мистификации (Лингвостиховедческий аспект. 3-5) // Philologica. Т. 5. № 11-13. 1998. С. 49-132.

Шенгели 1918 - Шенгели Г. А. Два «Памятника»: сравнительный разбор озаглавленных этим именем стихотворений Пушкина и Брюсова. Пг.: L'oiseau bleu, 1918.

Эфрос 1933 - Эфрос А. М. Рисунки поэта. М.: Academia, 1933.

Языков 1858 - Стихотворения Н. М. Языкова. СПб.: Тип. Имп. Академии наук, 1858.

Якобсон 1975 - Якобсон Р. О. Лингвистика и поэтика // Структурализм: за и против. М.: Прогресс, 1975. С. 193-230.

Якобсон 1987 - Якобсон Р. О. Статуя в поэтической мифологии Пушкина // Якобсон Р. О. Работы по поэтике: Переводы / Сост. и общ. ред. М.Л. Гаспарова. М.: Прогресс, 1987. C. $145-180$.

Ямпольский 1993 - Ямпольский М. Б. Память Тиресия: Интертекстуальность и кинематограф. М.: РИК «Культура», 1993.

Bethea 1998 - Bethea D. M. Realizing metaphors. Alexander Pushkin and the life of the poet. Madison: Univ. of Wisconsin Press, 1998.

Bowra 1964 - Bowra C. M. Pindar. Oxford: Clarendon Press, 1964.

Commager 1966 - Commager S. The odes of Horace. A critical study. New Haven: Yale Univ. Press, 1966.

Fraenkel 1957 - Fraenkel E. Horace. Oxford: Oxford Univ. Press, 1957.

Harrison 2001 - Harrison S. Simonides and Horace // The New Simonides: Contexts of praise and desire / Ed. by D. Boedeker, D. Sider. Oxford: Oxford Univ. Press, 2001. P. 261-264.

Juvan 2008 - Juvan M. History and poetics of intertextuality. West Lafayette, Indiana: Purdue Univ. Press, 2008.

Kahn 2008 - Kahn A. Pushkin's lyric intelligence. Oxford: Oxford Univ. Press, 2008.

Kelly $2001-$ Kelly C. Russian literature: A very short introduction. Oxford: Oxford Univ. Press, 2001.

Lowrie 1997 - Lowrie M. Horace's narrative odes. Oxford: Clarendon Press, 1997.

Nisbet, Rudd 2004 - A commentary on Horace: Odes, Book III / Ed. by R. G. M. Nisbet, N. Rudd. Oxford: Oxford Univ. Press, 2004.

Oliensis 1998 - Oliensis E. Horace and the rhetoric of authority. Cambridge: Cambridge Univ. Press, 1998.

Pöschl 1970 - Pöschl V. Horazische Lyrik: Interpretationen. Heidelberg: Carl Winter, 1970. 
Slings 2000 - Slings S. R. Aere Perennius - Which monument? // Ultima Aetas, time, tense and transience in the ancient world: Studies in Honour of Jan den Boeft / Ed. by C. Kroon, D. den Hengst. Amsterdam: Vrije Universiteit, 2000. P. 3-12.

Suerbaum 1968 - Suerbaum $W$. Untersuchungen zur Selbstdarstellung älterer römischer Dichter: Livius Andronicus, Naevius, Ennius. Hildesheim: Georg Olms, 1968.

Taillardat 1962 - Taillardat J. Les images d'Aristophane: Etudes de langue et de style. Paris: Les Belles-Lettres, 1962.

Thomas 1999 - Thomas R. F. Reading Virgil and his texts: Studies in intertextuality. Ann Arbor: Univ. of Michigan Press, 1999.

West 1969 - West M. L. Near Eastern material in Hellenistic and Roman literature // Harvard Studies in Classical Philology. Vol. 73. 1969. P. 113-134.

West 2009 - Horace Odes III. Dulce Periculum / Ed. by D. West. Oxford: Oxford Univ. Press, 2009.

Williams 1969 - The Third Book of Horace's Odes / Ed., trans, and comment. by G. Williams. Oxford: Oxford Univ. Press, 1969.

\section{FROM IMITATION TO REFUTATION: THE CANONISATION AND DECANONISATION OF THE METAPHOR OF POETIC MONUMENT IN RUSSIAN LITERATURE}

New, Katherine A.

$B A, M A$ (Oxon)

Postgraduate, Faculty of Medieval and Modern Languages,

University of Oxford

University College, High Street, Oxford, OX1 4BH, Great Britain

Tel.: 01865-276602

E-mail: katherine.new@univ.ox.ac.uk

Abstract. The article is devoted to studying the metaphor of poetry as an immaterial construction through the reception of Ho-race's Ode 3.30 in Russian literature (from Derzhavin and Pushkin to Bryusov, Mayakovsky, Khodasevich, Brodsky, Zakhoder and Purin, whose works have not been analysed before). The study of monument poetry leads to singling out its characteristic features: the dominating motif of the words of poetry as forming a more abiding monument than stone or bronze (which can potentially incur an egocentricity on the part of the poet); intertextuality ranging from allusion and direct quotation to bricolage, pastiche and parody; the unfolding of the basic metaphor through spatial and temporal perspectives. Pushkin's poem can be viewed as the source of the immense popularity of Horace's ode in Russia, which is incomparably greater than in the literature of other nations. Pushkin's own challenge to the canonical treatment of the metaphor is directed not only at Horace's but also at Derzhavin's poem, with which the canonization of the verbal monument tradition began in Russian literature. Subsequent polemic responses, including those of Bryusov and Mayakovsky, are invariably directed at Pushkin's poem, confirming its continuous presence in the collective memory of Russian-speaking 
nations. Later responses in what became a tradition tend to employ forms of parody that challenge or transform rather than destroy the verbal monument metaphor, maintaining it as an open system potentially available to postmodernistic literature, "defamiliarising" it through the prism of travesty, as in Brodsky's poem, or of irony, as in Khodasevich's or Zakhoder's parodies, or of bricolage, as in Purin's verse, whose success remains open to further challenge.

Keywords: metaphor, poetic monument, intertextuality, allusion, quotation, bricolage, parody, spatial perspective, temporal perspective, chronotope

\section{References}

Alekseev, M. P. (1967). Stikhotvorenie A. S. Pushkina "Ia pamiatnik sebe vozdvig...". (Problemy ego izucheniia) [Pushkin's poem I have erected a monument... Problems of study]. Leningrad: Nauka. (In Russian).

Averintsev, S. S. (1996). Sud'ba i vest' Osipa Mandel'shtama [The fate and message of Osip Mandelshtam]. In S. S. Averintsev. Poety [Poets], 189-273. Moscow: Shkola "Iazyki russkoi kul'tury". (In Russian).

Bakhtin, M. M. (1975). Formy vremeni i khronotopa v romane. Ocherki po istoricheskoi poetike [The forms of time and chronotope in the novel. Essays in historical poetics].

In M. M. Bakhtin. Voprosy literatury i estetiki [Problems of literature and aesthetics], 234-407. St. Petersburg, Moscow: Khudozhestvennaia literatura. (In Russian).

Baratynskii, E. A. (1936). Polnoe sobranie stikhotvorenii [Complete poetic works] (2 Vols.) (Vol. 1). Leningrad: Sovetskii pisatel'. (In Russian).

[Batiushkov, K. N.] (1886). Sochineniia K. N. Batiushkova [K. N. Batiushkov's works]. P. N. Batiushkov (Publ.), L. N. Maikov (Intro.), L. N. Maikov, V. I. Saitov (Notes) (Vol. 3). St. Petersburg: Tipografiia Kotomina. (In Russian).

Bethea, D. M. (1998). Realizing metaphors. Alexander Pushkin and the life of the poet. Madison: Univ. of Wisconsin Press.

Bowra, C. M. (1964). Pindar. Oxford: Clarendon Press.

Briusov, V. Ia. (1961). Stikhotvoreniia i poemy [Poems and longer poems]. Leningrad: Sovetskii pisatel'. (In Russian).

[Brodsky, J.] (2001). Sochineniia Iosifa Brodskogo [Joseph Brodsky's works] (7 Vols.) (Vol. 1). St. Petersburg: Izdatel'stvo Pushkinskogo fonda. (In Russian).

Commager, S. (1966). The odes of Horace. A critical study. New Haven, Conn.: Yale Univ. Press.

Derzhavin, G. R. (1957). Stikhotvoreniia [Poems]. Leningrad: Sovetskii pisatel'. (In Russian).

Efros, A. M. (1933). Risunki poeta [The poet's drawings]. Moscow: Academia. (In Russian).

Fedorov, I. V. (2005). Stikhi Igoria Fedorova [Igor Fedorov's poems]. Moscow: Izdatel'stvo N. Filimonova. (In Russian).

Feinberg, I. L. (1985). Chitaia tetradi Pushkina [Reading Pushkin's notebooks]. Moscow: Sovetskii pisatel'. (In Russian).

Fraenkel, E. (1957). Horace. Oxford: Oxford Univ. Press.

Frizman, L. G. (Ed., Comment. and Intro.) (1980). Vysokoe stremlen'e: Lirika dekabristov. [High aspirations: The Decembrists' lyrical poems]. Moscow: Detskaia literatura. (In Russian). 
Gasparov, M. L. (2000). Topika i kompozitsiia gimnov Goratsiia [Topics and composition of Horace's hymns]. In M. L. Gasparov. Ob antichnoi poezii: Poety. Poetika. Ritorika [On Classical poetry: Poets. Poetics. Rhetoric], 323-373. St. Petersburg: Azbuka. (In Russian).

Harrison, S. (2001). Simonides and Horace. In D. Boedeker, D. Sider (Eds.). The New Simonides: Contexts of praise and desire, 261-264. Oxford: Oxford Univ. Press

Iakobson [= Jakobson], R. O. (1987). Statuia v poeticheskoi mifologii Pushkina [The statue in Pushkin's poetic mythology]. In R. O. Iakobson. Raboty po poetike: Perevody [Works on Poetics. Translations], 145-180. Moscow: Progress. (In Russian).

Iampol'skii, M. B. (1993). Pamiat' Tiresiia: Intertekstual'nost' $i$ kinematograf [Tiresias' memory: Intertextuality and cinema. Moscow: RIK "Kul'tura". (In Russian).

[Iazykov, N. M.] (1858). Stikhotvoreniia N. M. Iazykova [Poems by N. M. Iazykov]. St. Petersburg: Tipografiia Imperatorskoi Akademii nauk. (In Russian).

Iliushin, A. A. (1978). Poeziia dekabrista G. S. Baten'kova. [The poetry of the Decembrist poet G. S. Baten'kov]. Moscow: MGU. (In Russian).

Juvan, M. (2008). History and poetics of intertextuality. West Lafayette, Indiana: Purdue Univ. Press.

Kahn, A. (2008). Pushkin's lyric intelligence. Oxford: Oxford Univ. Press.

Kelly, C. (2001). Russian literature: A very short introduction. Oxford: Oxford Univ. Press.

Khodasevich, V. F. (1924). Poeticheskoe khoziaistvo Pushkina [Pushkin's poetic household]. Leningrad: Mysl'. (In Russian).

Khodasevich, V. F. (1937). O Pushkine [About Pushkin]. Berlin: Petropolis. (In Russian).

Khodasevich, V. F. (1997). Sobranie sochinenii (4 Vols.). Moscow: Soglasie. (In Russian).

Klein, I. (2004). Poet-samokhval: "Pamiatnik" Derzhavina i status poeta v Rossii XVIII veka [The self-praising poet: Derzhavin's Monument and the status of poet in the $18^{\text {th }}$ century Russia]. Novoe literaturnoe obozrenie [New Literary Observer], 65, 148-169. (In Russian).

Lomonosov, M. V. (1986). Izbrannye proizvedeniia [Selected works]. Leningrad: Sovetskii pisatel'. (In Russian).

Lomonosov, M. V. (1959) Polnoe sobranie sochinenii [Full collection of works] (Vol. 8). Moscow; Leningrad: Izdatel'stvo AN SSSR. (In Russian).

Lowrie, M. (1997). Horace's narrative odes. Oxford: Clarendon Press.

Maiakovskii, V. V. (1960). Izbrannye proizvedeniia [Selected works] (Vols. 1-2). Moscow: Gosudarstvennoe izdatel'stvo khudozhestvennoi literatury. (In Russian).

Musorina, L. A. (2000). Podrazhaniia tridtsatoi ode Goratsiia v russkoi literature [Imitations of Horace's 30th Ode in Russian literature]. In Nauka. Universitet. 2000: Materialy Pervoi nauchnoi konferentsii [Science. University. 2000: Proceedings of the First conference], 86-90. Novosibirsk: Novyi sibirskii universitet. (In Russian).

Nepomniashchii, V. S. (1987). Poeziia i sud'ba. Nad stranitsami dukhovnoi biografii Pushkina [Poetry and fate. Over the pages of Pushkin's spiritual biography]. Moscow: Sovetskii pisatel'. (In Russian).

Nisbet, R. G. M., Rudd, N. (Eds.). (2004). A commentary on Horace: Odes, Book 3. Oxford: Oxford Univ. Press.

Oliensis, E. (1998). Horace and the rhetoric of authority. Cambridge: Cambridge Univ. Press.

Peskov, A. M. (1984). O poezii Lomonosova i o poezii Derzhavina [About Lomonosov's poetry and about Derzhavin's poetry]. In M. V. Lomonosov. G. R. Derzhavin. Izbrannoe [Selected works], 3-18. Moscow: Pravda. (In Russian).

Pöschl, V. (1970). Horazische Lyrik: Interpretationen. Heidelberg: Carl Winter. (In German).

Pumpianskii, L. V. (1977). Ob ode A. Pushkina "Pamiatnik" [About Pushkin's ode Monument]. Voprosy literatury [Problems of literature], 1977(8), 76-88. (In Russian). 
[Purin, A. A.] (2005). Sochineniia Alekseia Purina: Arkhaika/Evraziia [The works of Alexey Purin: Archaics/Eurasia]. St. Petersburg: Zvezda. (In Russian).

[Pushkin, A. S.] (1935). Rukoiu Pushkina: Nesobrannye i neopublikovannye teksty [By Pushkin's hand: Uncollected and unpublished texts]. Tsiavlovskii, M. A., Modzalevskii, L. B., Zenger, T. G. (Eds. and Comment.). Moscow; Leningrad: Academia. (In Russian).

Pushkin, A. S. (1962-1965). Polnoe sobranie sochinenii [ Complete collected works] (10 Vols.). $3^{\text {rd }}$ ed. Moscow: Nauka. (In Russian).

Raushenbakh, B. V. (1986). Sistemy perspektivy v izobrazitel'nom iskusstve [The systems of perspective in visual art]. Moscow: Nauka. (In Russian).

Shapir, M. I. (1997). Fenomen Baten'kova i problema mistifikatsii (Lingvostikhovedcheskii aspekt. 1-2) [The phenomenon of Batenkov and the problem of mystification. The linguoversificatory aspect. 1-2]. Philologica, 4(8-10), 85-144. (In Russian).

Shapir, M. I. (1998). Fenomen Baten'kova i problema mistifikatsii (Lingvostikhovedcheskii aspekt. 3-5) [The phenomenon of Batenkov and the problem of mystification. The linguoversificatory aspect. 3-5]. Philologica, 5(11-13), 49-132. (In Russian).

Shengeli, G. A. (1918). Dva "Pamiatnika": sravnitel'nyi razbor ozaglavlennykh etim imenem stikhotvorenii Pushkina i Briusova [Two Monuments: A comparative study of corresponding poems by Pushkin and Bryusov]. Petrograd: L'oiseau bleu. (In Russian).

Slings, S. R. (2000). Aere Perennius - Which monument? In C. Kroon, D. den Hengst (Eds.). Ultima Aetas, time, tense and transience in the ancient world: Studies in honour of Jan den Boeft, 3-12. Amsterdam: Vrije Universiteit.

Stepanov, N. L. (1938). V. Ia. Briusov v rabote nad Pushkinym [Valery Bryusov working on Pushkin]. In S. D. Balukhatyi et al. (Eds.). Literaturnyi arkhiv: Materialy po istorii literatury i obshchestvennogo dvizheniia [Literary archive: Materials on the history of literature and social movements], 302-351. Moscow; Leningrad: Izdatel'stvo AN SSSR. (In Russian).

Suerbaum, W. (1968). Untersuchungen zur Selbstdarstellung älterer römischer Dichter: Livius Andronicus, Naevius, Ennius. Hildesheim: Georg Olms. (In German).

Surat, I. Z. (2009). Mandel'shtam i Pushkin [Mandelshtam and Pushkin]. Moscow: IMLI RAN. (In Russian).

Taillardat, J. (1962). Les images d'Aristophane: Etudes de langue et de style. Paris: Les BellesLettres. (In French).

Thomas, R. F. (1999). Reading Virgil and his texts: Studies in intertextuality. Ann Arbor: Univ. of Michigan Press.

Tynianov, Iu. N. (1977) O parodii [On parody]. In Iu. N. Tynianov. Poetika. Istoriia literatury. Kino [Poetics. History of literature. Cinema], 284-309. Moscow: Nauka. (In Russian).

Vatsuro, V. E. (2000). Pushkinskaia pora [Pushkin's epoch]. St. Peterburg: Akademicheskii proekt. (In Russian).

Veselovskii, A. N. (1989). Istoricheskaia poetika [Historical poetics]. Moscow: Vysshaia shkola. (In Russian).

Voitekhovich, R. S. (2000). O goratsianskom pretekste "Ia pamiatnik sebe vozdvig nerukotvornyi..." [On the Horatian pretext of I have erected a monument]. In L. Kiseleva (Ed.). Pushkinskie chteniia v Tartu [The Pushkin Readings in Tartu] (Vol. 2), 228-234. Tartu: Tartu Ülicooli Kirjastus. (In Russian).

West, M. L. (1969). Near Eastern material in Hellenistic and Roman literature. Harvard Studies in Classical Philology, 73, 113-134.

West, D. (Ed). (2009). Horace Odes III. Dulce Periculum. Oxford: Oxford Univ. Press.

Williams, G. (Ed., Trans., Comment.) (1969). The Third Book of Horace's Odes. Oxford: Oxford Univ. Press. 
Zakhoder, B. V. (1996). Pochti posmertnoe [Nearly posthumous]. Moscow: GKTsM Dom Vysotskogo; ITs "Vagant". (In Russian).

Zhiliakov, S. V. (2010). Zhanrovaia traditsiia stikhotvoreniia- "Pamiatnika" v russkoi poezii $X V I I I-X X v v$. [The genre tradition of the Monument poem in Russian poetry of the $18-20^{\text {th }}$ centuries]: Thesis for the degree of Candidate of Philology (Yelets State University named after I. A. Bunin). (In Russian).

Zhivov, V. M. (1996). Gosudarstvennyi mif v epokhu Prosveshcheniia i ego razrushenie v Rossii kontsa XVIII veka [The state myth in the period of Enlightenment and its destruction in Russia in the late $18^{\text {th }}$ century]. In Yu. M. Lotman, V. M. Zhivov, S. S. Averintsev et al. Iz istorii russkoi kul'tury [From the history of Russian culture] (Vol. 4), 657-684. Moscow: Iazyki russkoi kul'tury. (In Russian).

To cite this article:

New, K. A. (2018). From imitation to Refutation: The CANONisation and DECANONISATION OF THE METAPHOR OF A POETIC MONUMENT IN RUSSIAN LITERATURE. SHAGI / STEPS, 4(3), 247-274. 